This is the post print version of the article, which has been published in International Review of Retail, Distribution and Consumer Research. 2017, 27 (5), 485-501. http://dx.doi.org/10.1080/09593969.2017.1383289

D This document has been downloaded from TamPubutafi The Insitutional Repository of University of Tampere

\title{
The Impact of Consumer Local Engagement on Local Store Patronage and Customer Satisfaction
}

Mika Skippari, University of Tampere, Finland,

Mailing address: FI-33014 Tampereen yliopisto

Phone: +3583355111

Email: mika.skippari@uta.fi

Jussi Nyrhinen, University of Jyvaskyla, Finland,

Mailing address: School of Business and Economics, P.O. Box 35, 40014 University of Jyvaskyla

Phone: +358142601211

Email: jussi.nyrhinen@jyu.fi

Heikki Karjaluoto, University of Jyvaskyla, Finland,

Mailing address: School of Business and Economics, P.O. Box 35, 40014 University of

Jyvaskyla

Phone: +358142601211

Email: heikki.karjaluoto@jyu.fi

\begin{abstract}
This paper examines the drivers of local grocery retail patronage. Drawing on institutional and social network theory literature, we develop a framework to investigate how consumers' personal values and engagement with local communities affect their satisfaction and local store patronage. We test our model with survey data on 1504 Finnish consumers. Our results show that the relationship between customer local engagement and local retail patronage is indirect rather than direct, and it is mediated by the vitality of local services, social interaction, and consumer satisfaction.
\end{abstract}

Keywords: local retail patronage, consumer community values, local community engagement, consumer satisfaction, social capital

\section{Introduction}

The performance and even survival of small local neighborhood retailers amidst intensifying competition by international retailers and large-scale retail formats (such as supermarkets and hypermarkets) has been increasingly threatened both in developed (Megicks 2007; Miller et al. 2003; Brennan and Lundsten 2000) and developing markets (Sinha and Banerjee 2004; Uncles 
and Kwok 2008). Local small retailers face the "triple jeopardy" phenomenon of having fewer customers who make fewer visits and spend less per visit (Bhat and Fox 1996), so they are seeking effective marketing strategies to counter this development. Although the question of why customers patronize small local stores is important to academics and practitioners alike, the perspective of rural and local retail patronage is understudied in the marketing literature (Pan and Zinkhan 2006). While previous research has extensively studied consumer outshopping behavior, i.e., consumers' tendency to shop out of their local area (Hozier and Stem 1985), fewer studies have examined why consumers favor the services of local retailers (i.e., inshopping behavior) (Kim and Stoel 2010). In general, there is still a need for more theory-based research focusing on consumer behavior in the small retailing context (e.g., Brown and Dant 2006; Runyan and Droge 2008).

As shown in the meta-analysis conducted by Pan and Zinkhan (2006), previous studies have primarily focused on product-relevant (i.e., product quality, price), market-relevant (i.e., convenience, service quality), and personal factors (i.e., demographics, attitude towards a store) as antecedents to retail patronage. Few studies have investigated store patronage from the standpoint of local communities, although understanding the effects of community involvement could lead to considerable strategic advantages, especially for small local retailers (Runyan and Droke 2008). Recently, however, an increasing number of researchers have studied the importance of various social and community-based factors to explain local store patronage (Goswami and Mishra 2009; Landry et al. 2005; Kim and Stoel 2010; Miller and Kean 1997). In this stream of research, the key tenet is to address the inherently social nature of the shopping process and to emphasize that small local stores meet a variety of social, sustainability, and ethical needs (Megicks 2007; Clarke and Banga 2010). Accordingly, consumers evaluate the services of local retailers not only based on their task-oriented actions, but also on the extent of their institutional actions, such as participating in community events and hiring local workers (Handelman and Arnott 1999). In the local context, understanding the effects of community involvement and attachment can lead to significant strategic advantages for small retailers. Prior studies have established that a firm's support for and commitment to the local community is positively linked to its performance (Besser 1999; Miller and Besser 2013) and retail patronage (Landry et al. 2005; Kim and Stoel 2010). In addition, Handelman and Arnold (1999) found that marketing actions with a social dimension had a positive effect on consumers' support (i.e., patronage) of a retailer.

Previous research has focused on analyzing the link between community embeddedness and patronage from a retailer's perspective (Landry et al. 2005; Noble et al. 2006; Miller and Besser 2013), thus increasing our knowledge of how local retailer's actions for supporting and reviving local communities can lead to increased patronage among local customers. However, fewer studies have examined the role of consumers' community-based values (such as engagement with local community actions, preference for supporting local services, and social interaction with other consumers and store personnel) in determining local store patronage. Miller (2001) found that consumers' community attachment (i.e., active involvement in community activities, and positive sentiment towards the community) was positively related to inshopping behavior in their rural stores. Kim and Stoel (2010) examined the mediating role of the local community's social capital in explaining the relationship between retailer's institutional actions and consumer patronage. In addition, although it has been noted that dissatisfaction with local offerings is a major contributing factor to outshopping behavior (Miller 2001), no prior studies have examined how consumers' community-based values are linked to their satisfaction with, and ultimately, patronage to local retailers.

The present study aims to extend existing research by explicitly examining the drivers of local grocery retail patronage from the consumers' point of view. We posit that, in explaining local 
store patronage, it is essential to consider the standpoint of local communities and the personal values of local customers. Drawing on the literature of institutional and social network theory, we developed a framework to investigate how consumers' values related to local engagement, social interaction, and vitality of local services affect consumer satisfaction and local store choice. The analysis, based on a survey of 1504 consumers in Finland, demonstrates that consumers' social and community values play an important role in driving satisfaction and local store patronage.

\section{The conceptual model and hypotheses}

In building our conceptual framework, we relied on the theoretical insights of institutional theory (Dacin 1997; Scott 1987) and social network theory (Granovetter 1985; Coleman 1988), combined with earlier literature on retail patronage that emphasized the importance of local engagement and societal embeddedness for local retailers (Kim and Stoel 2006; Landry et al. 2005; Miller and Kean 1997; Miller 2001; Noble et al. 2006). Since our primary interest was to explain the effects of consumers' local values (expressed as engagement and involvement in community building activities) on local grocery store patronage, we focused on three key constructs (consumer local engagement, social interaction, and the vitality of local services) to examine their effects on local retail patronage and customer satisfaction (Figure 1). In the following section, we elaborate on the theoretical basis of our framework and present our hypotheses.

Figure 1. Conceptual model for studying the effect of consumer local engagement and personal values on local store patronage

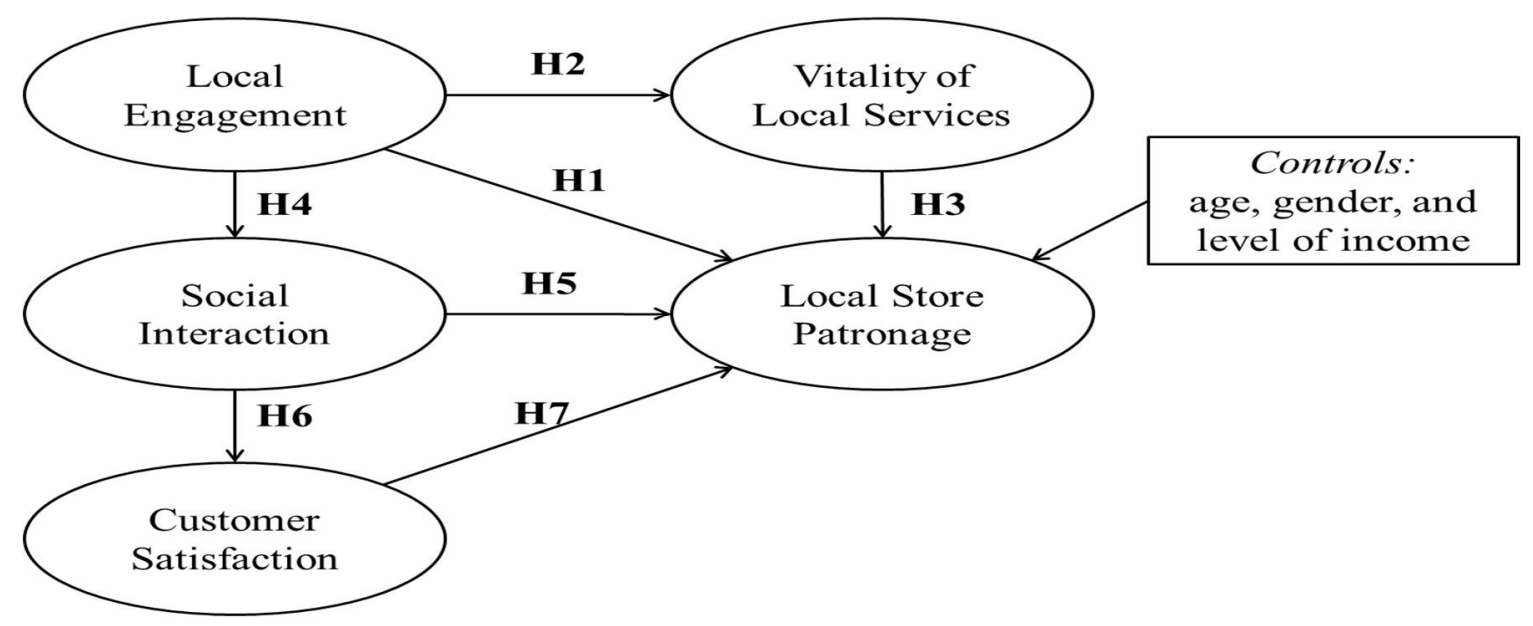

Retail patronage, commonly conceptualized as a consumer's choice of store or frequency of visits to a store, has been widely examined in different contexts: retailing in general, rural and local retailing (e.g., outshopping and inshopping behavior), and among small independent retailers (see the meta-analysis by Pan and Zinkhan 2006). There is extensive evidence that 
consumers seldom shop exclusively at a single retail format or a single store within a format. Instead, they prefer to spread their store visits and purchases across multiple store formats that can satisfy their shopping needs (e.g. Carpenter and Moore 2006; Cummins et al. 2008; Ganesh, Reynolds, and Luckett 2007). However, understanding why consumers choose to favor a specific kind of store format is crucial. Accordingly, patronage behavior has been a subject of studies that seek to develop shopper taxonomy and to explore the relative importance of store patronage motives indicating the reasons why consumers shop and make purchases at specific retail stores (Morschett et al. 2005; Ganesh et al. 2007).

In the local retail context, commonly explored shopping motives include convenience, information attainment, credit sales, and personalized service (Brennan and Lundsten 2000; Goswami and Mishra 2009; Noble et al. 2006). In addition, familiarity with small local stores (Paswan et al. 2010), various consumer shopping styles (Jayasankaraprasad and Gonuguntla 2014), and consumer lifestyles (Sullivan and Savitt 1997) have been found to be key predictors for local store patronage. Indeed, small local retailers can distinguish themselves and gain competitive advantage against big-box retailers by providing consumers with personal service and detailed product information (Brennan and Lundsten 2000). In addition, local retailers' role in reviving and supporting local communities has been identified as a central distinguishing factor (Runyan and Droke 2008; Clarke and Banga 2010).

\section{Consumer local engagement}

The concept of social embeddedness (Granovetter 1985) is widely used to describe the social relationships between consumers and retailers in local communities. Based on Granovetter's (1985) theory of embeddedness, it can be argued that retailers and consumers are community members bound by shared histories and ongoing social relationships. Through these social connections, the behavior of community members is embedded in social networks, which enables the production of social capital (Coleman 1988) within the community. Similarly, according to social identification theory, retailers and local communities can be seen as meaningful social categories that consumers identify with (Bhattacharya and Sen 2003). Therefore, members of communities with dense social networks possess high levels of social capital and strong community identification, which makes them more likely to engage in activities that support and enhance the well-being of the community and the vitality of retail services within the community.

Typically, the social environment of local communities can be characterized as having dense social networks that can facilitate the accumulation of social capital. Many studies have emphasized the importance of local retail engagement and socialization actions in explaining why local consumers choose to use local retail services (Miller 2001; Kim and Stoel 2010; Landry, Arnold, and Stark 2005). Small local retailers use community embeddedness and informal but meaningful interpersonal relationships between shop owners and customers as the key pillars for their localization strategic marketing approach (Coca-Stefaniak et al. 2010).

Specifically, the importance of social capital in local communities has been found to be crucial for local retail performance and patronage. For example, Cowell and Green (1994) reported that consumers' sentiments toward their community influenced where they shopped (Miller 2001). Miller and Kim (2000) showed how consumer/retailer exchange activities are embedded in the social structure of a community, and how higher levels of community attachment increase local store patronage. Kim and Stoel (2010) proposed that, in a community where consumers perceive a high level of social capital, they place more value on the institutional actions of local retailers and will support them. Similarly, Besser and Miller (2013) found that 
entrepreneurs in high bridging social capital towns were more successful, and community bridging social capital may enhance their success by helping to retain and attract skilled labor, reduce costs, provide access to capital, and engender customer loyalty in residents.

Based on the above discussion, we propose that the level of social capital within a community affects the community members' decision to use the services of local retailers. Thus, we hypothesize that there is a direct link between consumer local engagement and local store patronage.

H1: Local Engagement has a positive association with Local Store Patronage.

\section{Vitality of local services}

According to institutional theory (Dacin 1997; Scott 1987), retailers have to either comply with or exceed institutional norms in order to be successful in the long run (Arnold, Handelman, and Tigert 1996; Pioch et al. 2009). By adapting to these norms, retailers seek social legitimacy, which can be achieved if an organization's actions are consistent with upholding the welfare of the community and society (Suchman 1995). Seeking legitimacy and gaining support from community members (e.g., local consumers) involves task-oriented actions as well as institutional actions, such as participating in community events, donating to community charities, working with local suppliers, and employing local workers (Handelman and Arnold 1999; Kim and Stoel 2010). In fact, Handelman and Arnold (1999) found that poor adherence to a societal norm (e.g., engagement in community-supporting actions) could weaken the positive relationship between an economic norm (e.g., having competitive prices or convenient location) and retail patronage. Kim and Stoel (2010) showed how social capital within a community draws consumers' attention to the retailers' institutional actions, leading to inshopping behavior.

Consumers' attitudes toward local retailers (Miller and Kean 1997; Pan and Zinkhan 2006) and their support of them (Noble et al. 2006; Kim and Stoel 2010) are essential for local retail performance and success. By adhering to the institutional norms of a local community, retailers make themselves locally relevant; thus, they can affect consumers' attitudinal perceptions of the retailers' community membership. In turn, local consumers, having perceived the retailer as being a locally relevant member of the community, are willing to support the retailer. The reciprocity between retailer and customer, conceptualized as the norm for support of local businesses (Landry et al. 2005), enables community members to achieve mutually beneficial outcomes (Miller and Kim 1997; Miller and Besser 2000). For example, consumers may choose to shop at small retailers' stores because they feel these stores help the local community (Paswan et al. 2010). Similarly, small retailers that have higher community values are more willing to work for the betterment of the community (e.g., work to strengthen the local community, cooperate with other local businesses) (Miller and Besser 2000). Importantly, reciprocity seems to be linked to community social capital, as consumers that perceive a high level of social capital are more willing to make purchase decisions that benefit the community than those that perceive a low level of social capital (Kim and Stoel 2010).

In summary, both the reciprocity between a retailer and its customers (Landry et al. 2005) and a retailer's adherence to institutional norms within the community (Handelman and Arnold 1999) have been shown to have a positive effect on consumer patronage. Conceptually, both reciprocity and adherence to institutional norms refer to developing a shared emotional connection between consumers and retailers, which leads to a shared commitment to and an understanding of the importance of the vitality of local services. Accordingly, we assume that 
consumers who are highly committed to local community actions (indicating strong local engagement) are also willing to support the survival and development of local services. Consumers who show a preference for supporting the vitality of local services are also more prone to use local retailers as their primary place for shopping. Therefore, we hypothesize:

H2: Local Engagement has a positive association with Vitality of Services.

H3: Vitality of Services has a positive association with Local Store Patronage.

\section{Social interaction}

Stemming from the work of Tauber (1972), the concept of retail social interaction posits that retail stores are places for humans to interact (Pan and Zinkhan 2006) and congregate (Landry et al. 2005). As such, they offer consumers an opportunity to satisfy various social needs and motives, such as enjoying talking with other customers and communicating with salespeople during a shopping visit (Maruyama and Wu 2014). Indeed, social shoppers have been found to be a major consumer segment in grocery shopping (Arnold and Reynolds 2003; Nilsson et al. 2015).

The significance of social interaction seems to be especially important for local retailers. In the minds of consumers, a local retailer's value is derived from the perception that the store is a place for congregation and engagement in community interaction (Landry et al. 2005). Clarke and Banga (2010) noted that small local stores can provide a hub for social interaction within communities. Home (2002) suggested that strengthening social interaction and providing local people with the opportunity to be more involved in their local store could motivate customers to utilize services in their neighborhood. Social interaction has been recognized as a key driver of customer loyalty to local merchants (Noble et al. 2006; Clarke and Banga 2010). Similarly, previous studies have found that social interaction is positively related to store patronage behavior (Goswami and Mishra 2009; Noble et al. 2006). According to Brennan and Lundsten (2000), consumers patronize local retailers because they have formed personal relationships with the store staff.

Based on the above discussion, we posit that consumers who are actively engaged in local community actions also seek social interaction when they visit a local store. In addition, we assume that social interaction is a key driver for local store patronage. Accordingly, we hypothesize:

H4: Local Engagement has a positive association with Social Interaction.

H5: Social Interaction has a positive association with Local Store Patronage.

\section{Consumer satisfaction}

Earlier research suggests that consumer satisfaction with a retailer has important implications on retail performance and patronage (Lombard and Louis 2012; Zeithaml, Berry, and Parasuraman 1996). In addition, satisfaction is often a prerequisite for loyalty in that consumers are more likely to return to a retailer if they are satisfied with the goods and services the store provides (LaBarbera and Mazursky 1983; Zeithaml, Berry, and Parasuraman 1996). In contrast, dissatisfaction with a local retail offering is a major factor that contributes to outshopping behavior (Miller 2001). However, consumer satisfaction is affected by different store attributes, such as price level, store image, supply quality, and service quality (Huddleston et al. 2009; 
Nilsson et al. 2017), and consumers want different things from different types of shopping (Bell, Corsten, and Know 2011).

Previous studies have mainly focused on analyzing store formats (e.g., supermarkets, convenience stores, discount stores), store attributes (product range, price level, service quality), and type of grocery shopping (major vs. fill-in shopping) to explain customer satisfaction with grocery shopping (Hsu et al. 2010; Huddleston et al. 2009; Nilsson, Gärling, and Marell 2013). However, the effects of customer satisfaction in a local retail context have not yet been investigated. The role of social interaction is especially relevant in local retailing (Goswami and Mishra 2009; Noble et al. 2006). Moreover, social relationship benefits (such as enjoying a salesperson's company and/or close relationship, having a good friend, and enjoying spending time with a salesperson) have been shown to have a positive association with customer satisfaction and loyalty to both a company and a specific salesperson (Reynolds and Beatty 1999). Thus, we hypothesize that there is a positive link between social interaction and consumer satisfaction. In addition, we assume that consumer satisfaction is a key driver for local store patronage.

H6: Social Interaction has a positive association with Consumer Satisfaction.

H7: Consumer Satisfaction has a positive association with Local Store Patronage.

\section{Context and research methodology}

\section{Context}

Finland is a good research environment for this kind of study; while it is a post-industrial affluent society, it is rather young as a consumer society. Urbanization and consumptionoriented lifestyles emerged late in Finland (Autio and Heinonen 2004; Wilska 2002). The Finnish grocery retail market is highly concentrated; the three largest grocery trade groups hold a 92\% market share, including small local stores. The structure of grocery trade has changed over the last decade; the total number of grocery stores has decreased to one-third, and supermarkets and hypermarkets have become the dominant retail format, accounting for $81 \%$ of all grocery sales. Both market share and total sales of small grocery stores (less than 400 square meters) have been continuously decreasing. However, small grocery retail stores still comprise two-thirds of the trade service network, and they continue to play a significant role as local service providers in maintaining the food supply throughout the country (Finnish Grocery Trade 2017).

\section{Sample and data collection}

The data for the present study were collected in October 2013 by surveying 1504 Finnish consumers ranging in age between 18 and 75, using a structured Internet panel. The data collection was complemented with telephone interviews for consumers that are older than 65 because they do not use the Internet as commonly as people in the other age groups (OSF 2010). The respondents were chosen using random sampling with quotas so that the data would represent the entire adult population of Finland. The minimum quota was set at 1500 valid responses; 1300 responses were collected from respondents between the ages of 18 and 65 by the Internet panel and 200 telephone interviews with respondents between the ages of 66 and 75. Telephone interviews were conducted in such a way that the data collected with both 
methods could be combined into one file. Moreover, age and gender quotas were set so that the data would represent the entire Finish population. The generalizability of the sample was analyzed by comparing it to The Official Statistics of Finland: Population (2010), Income and Consumption (2009), and Education (2009). The data was a representative sample of the population, although some demographic groups were approximately 1-5\% over- or underrepresented.

\section{Measurements and analytical approach}

The survey form included, among other themes and questions not relevant to this study, 25 opinion and attitude statements related to local grocery store patronage. Respondents evaluated these statements using a Likert-type scale (1=strongly disagree to 5=strongly agree).

A series of items was generated to measure the key constructs of the study (see Appendix 1). Following the standard procedure in retail patronage studies, we operationalized patronage behavior as shopping frequency (Pan and Zinkhan 2006). Thus, to measure our dependent variable, local store patronage, we used three items drawn from Grewal et al. (2003) and Noble et al. (2006). Local engagement of consumers was generated using indicators regarding the consumers' sentiments and their involvement in the community from four modified items drawn from Miller and Besser (2000), Kim and Stoel (2010), Landry et al. (2005), and Pioch et al. (2009). This measure aimed to capture the extent to which consumers value and engage in the development of their local community. Three items to measure the importance of social interaction at a local store were adopted from Home (2002) and from the framework of Noble et al. (2006). The measure for the vitality of local services was generated using three items to capture consumers' attitudes toward local retailers (Miller and Kean 1997), support of local retailers (Noble et al. 2006; Kim and Stoel 2010), and the norm of reciprocity (Landry et al. 2005). Three items measuring consumer satisfaction with a retailer were derived from Lombard and Louis (2012) and Zeithaml and Berry (1996). In addition, as previous studies have widely acknowledged that consumer demographic and socio-economic variables may be associated with retail patronage (Pan and Zinkhan 2006; Noble et al. 2006), we used three control variables: age, gender, and level of income.

First we conducted exploratory factor analysis to identify the components of local merchant loyalty. Subsequently, the data were analyzed using Partial Least Squares (PLS) confirmatory factor analysis (PLS-SEM).

\section{Common method bias}

The following procedure was used to mitigate the likelihood of common method bias tainting the results. The items were mixed in the questionnaire, item ambiguity was reduced, and the respondents' identities were kept confidential. Two statistical analyses were performed to test for possible common method bias. First, Harman's one-factor test showed the presence of measurement model factors rather than a general factor. The largest factor accounted for $35.07 \%$ of the total variance of the factors. Second, a model with a common method factor was run in SmartPLS. The results showed that the average method based variance was lower $(0.007)$ than the average variance explained by the indicators $(0.688)$. These tests provide evidence that common method bias is not a concern in our dataset. 


\section{Analyses and results}

\section{Assessment of the measurement model}

The final model of the factor analysis included 16 variables with sufficiently high communality $\left(\mathrm{h}^{2} \geq 0.4\right)$ and factor loadings $(\geq 0.45)$. In general, the construct measures showed high internal reliability because the composite reliabilities were all equal to or larger than 0.844 and Cronbach's alphas were larger than the recommended cut-off value of 0.70 . Discriminant validity was achieved using the Fornell-Larcker criterion, which is based on the premise that a latent variable should better explain the variance of its own indicators than the variance of other latent variables, and then testing the Heterotrait-Monotrait (HTMT) ratio. Table 1 shows the cross-correlation matrix in which the square root of the average variance extracted (AVE) is compared to the correlations between the latent variable and all other latent constructs. In addition, Table 1 shows the mean scores for the constructs and their standard deviations. The square root of the AVE of each latent variable exceeded the correlations with all the other latent variables, and all the HTMT ratios were below the cut-out value of 0.90 .

PLS does not provide model fit statistics similar to covariance-based Structural Equation Modeling (SEM); thus, Henseler et al. (2014) suggested that the standardized root mean square residual (SRMR) should be used to evaluate the model fit in PLS. Values less than 0.08 are considered a good fit in common factor models. In the present study, the SRMR value is 0.060 , which is well below the threshold, thus, indicating good fit. Thus, the evaluation of the reflective and formative constructs meets the criteria set in the literature.

Table 1. Average variance extracted (AVE), reliabilities, construct correlations, square root of AVE (on the diagonal), means, and standard deviations (SDs).

\begin{tabular}{|c|c|c|c|c|c|c|c|c|c|c|}
\hline & AVE & $\mathrm{CR}^{\mathrm{a}}$ & (1) & (2) & (3) & (4) & (5) & (6) & (7) & (8) \\
\hline $\operatorname{VIT}^{\mathrm{b}}(1)$ & 0.720 & 0.885 & 0.849 & & & & & & & \\
\hline $\operatorname{SAT}^{\mathrm{c}}(2)$ & 0.720 & 0.885 & 0.440 & 0.849 & & & & & & \\
\hline $\operatorname{PAT}^{\mathrm{d}}(3)$ & 0.645 & 0.844 & 0.437 & 0.516 & 0.803 & & & & & \\
\hline $\operatorname{INT}^{\mathrm{e}}(4)$ & 0.693 & 0.871 & 0.329 & 0.201 & 0.313 & 0.832 & & & & \\
\hline $\mathrm{ENG}^{\mathrm{f}}(5)$ & 0.639 & 0.876 & 0.439 & 0.175 & 0.223 & 0.413 & 0.799 & & & \\
\hline $\operatorname{AGE}^{\mathrm{g}}(6)$ & $\mathrm{n} / \mathrm{a}$ & $\mathrm{n} / \mathrm{a}$ & 0.174 & 0.031 & 0.052 & 0.243 & 0.213 & $\mathbf{n} / \mathbf{a}$ & & \\
\hline $\mathrm{GEN}^{\mathrm{h}}(7)$ & $\mathrm{n} / \mathrm{a}$ & $\mathrm{n} / \mathrm{a}$ & -0.089 & -0.086 & -0.026 & 0.028 & 0.002 & 0.021 & $\mathbf{n} / \mathbf{a}$ & \\
\hline $\operatorname{INC}^{\mathrm{i}}(8)$ & $\mathrm{n} / \mathrm{a}$ & $\mathrm{n} / \mathrm{a}$ & 0.045 & -0.046 & -0.026 & -0.044 & 0.083 & 0.222 & 0.190 & $\mathbf{n} / \mathbf{a}$ \\
\hline Mean & - & - & 3.283 & 3.380 & 2.82 & 2.58 & 2.588 & 3.410 & $\mathrm{n} / \mathrm{a}$ & 2.140 \\
\hline SD & - & - & 1.105 & 1.026 & 1.286 & 1.183 & 1.685 & 1.653 & $\mathrm{n} / \mathrm{a}$ & 0.827 \\
\hline Cronbach's Alpha & - & - & 0.807 & 0.806 & 0.727 & 0.779 & 0.813 & $\mathrm{n} / \mathrm{a}$ & $\mathrm{n} / \mathrm{a}$ & $\mathrm{n} / \mathrm{a}$ \\
\hline
\end{tabular}

\section{Assessment of the structural model}

To test our hypotheses, we examined the direct effects, followed by an analysis of the mediation effect, including an assessment of the indirect and total effects. The significance of the paths was assessed using bootstrapping with 5,000 re-samples. The results of the PLS estimation for the direct effects are presented in Table 2. 
Table 2. The direct effects of the model.

\begin{tabular}{lccc}
\hline & $\beta$ & $f^{2}$ & $q^{2}$ \\
\hline H1: Local Engagement $\rightarrow$ Local Store Patronage & $-0.005(\mathrm{~ns})$ & 0.035 & 0.220 \\
H2: Local Engagement $\rightarrow$ Vitality of Local Services & $0.437^{* * *}$ & n/a & $\mathrm{n} / \mathrm{a}$ \\
H3 Local Engagement $\rightarrow$ Social Interaction & $0.413^{* * *}$ & $\mathrm{n} / \mathrm{a}$ & $\mathrm{n} / \mathrm{a}$ \\
H4: Vitality of Local Services $\rightarrow$ Local Store Patronage & $0.221^{* * *}$ & 0.097 & 0.006 \\
H5: Social Interaction $\rightarrow$ Local Store Patronage & $0.173^{* * *}$ & 0.037 & -0.020 \\
H6: Social Interaction $\rightarrow$ Customer Satisfaction & $0.201^{* * *}$ & 0.020 & 0.106 \\
H7: Overall Satisfaction $\rightarrow$ Local Store Patronage & $0.388^{* * *}$ & 0.223 & 0.002 \\
& & & \\
Age $\rightarrow$ Local Store Patronage & $-0.040(\mathrm{~ns})$ & 0.036 & -0.017 \\
Gender $\rightarrow$ Local Store Patronage & $0.024(\mathrm{~ns})$ & 0.038 & -0.018 \\
Level of Income $\rightarrow$ Local Store Patronage & $-0.002(\mathrm{~ns})$ & 0.036 & -0.018 \\
& $R^{2}$ & $Q^{2}$ & \\
Local Store Patronage & 0.347 & 0.204 & \\
\hline
\end{tabular}

Notes: $* * * p<0.01$; ns: not significant; n/a: not applicable

Overall, the model explained over $35 \%$ of the $R^{2}$ of Local Store Patronage. The $Q^{2}$ value was larger than 0.2 for Local Store Patronage, indicating medium-large predictive relevance. Local Engagement was found to have strong positive associations with Vitality of Local Services $(\beta$ $=0.437, p<0.01)$ and Social Interaction $(\beta=0.173, p<0.01)$, providing support for $\mathrm{H} 4$ and $\mathrm{H} 5$. The data supported positive associations with respect to H2-H3 and H6-H7. However, our findings do not support the direct positive association between Local Engagement and Local Store Patronage (H1). Instead, the model confirms the indirect paths between Local Engagement and Local Store Patronage via Vitality of Local Services, Social Interaction, and Overall Satisfaction. The results of the total effects (Table 3) confirm our hypotheses by showing that Local Engagement has a significant positive association with Local Store Patronage $(0.196, p<0.01)$, but the effect is more indirect than direct. None of the control variables (gender, age, level of income) have a significant association with Local Store Patronage.

Table 3. Total effects of the model.

\begin{tabular}{ccccc}
\hline & INT & VIT & SAT & PAT \\
\hline Vitality of Local Services (VIT) & - & - & - & $0.221^{* * * a}$ \\
Overall Satisfaction (SAT) & - & - & - & $0.388^{* * * a}$ \\
Social Interaction (INT) & - & - & $0.200^{* * * a}$ & $0.251^{* * *}$ \\
Local Engagement (ENG) & $0.413^{* * * a}$ a & $0.438^{* * * a}$ & $0.082^{* * *}$ & $0.196^{* * *}$ \\
\hline Notes: ${ }^{* * * *} p<0.01 ;{ }^{\text {a }}$ Same as the direct effect & & &
\end{tabular}

Finally, we examined how the effect of Local Engagement on Store Patronage is mediated by Social Interaction, Overall Satisfaction, and Vitality of Local Services. To assess these relationships, the indirect effects and mediation were assessed by calculating the significance of the indirect effects by bootstrapping the sampling distribution $(5,000$ bootstrap samples, no 
sign changes) and calculating the variance accounted for (VAF) value (Preacher and Hayes, 2008). The results demonstrate that the effects of Local Engagement on Local Store Patronage are fully mediated through Vitality of Local Services (VAF=1.02) and partially mediated through Social Interaction and Customer Satisfaction (VAF=0.310). The result of this analysis is shown in Table 4.

Table 4. Indirect effects and mediation results.

\begin{tabular}{|c|c|c|c|c|}
\hline & $\begin{array}{l}\text { Indirect } \\
\text { effects }\end{array}$ & $\begin{array}{l}\text { Total } \\
\text { effects }\end{array}$ & VAF & Mediation \\
\hline ENG $\rightarrow$ PAT (through INT and SAT) & $0.075^{* * *}$ & $0.000 * * *$ & $\mathrm{n} / \mathrm{a}$ & No \\
\hline $\mathrm{ENG} \rightarrow \mathrm{INT} \rightarrow \mathrm{PAT}^{\mathrm{b}}$ & $0.063 * * *$ & $0.068 * * *$ & 0.927 & Full \\
\hline $\mathrm{ENG} \rightarrow \mathrm{SAT} \rightarrow \mathrm{PAT}^{\mathrm{b}}$ & $-0.020 * * *$ & $0.334 * * *$ & 0.774 & Full \\
\hline $\mathrm{ENG} \rightarrow \mathrm{INT} \rightarrow \mathrm{SAT} \rightarrow \mathrm{PAT}^{\mathrm{b}}$ & $0.032 * * *$ & $0,027 * * *$ & $\mathrm{n} / \mathrm{a}$ & No \\
\hline $\mathrm{ENG} \rightarrow \mathrm{VIT} \rightarrow \mathrm{PAT}$ & $0.097 * * *$ & $0.102 * * *$ & 0.951 & Full \\
\hline $\mathrm{INT} \rightarrow \mathrm{SAT} \rightarrow \mathrm{PAT}$ & $0.060 * * *$ & $0.233 * * *$ & 0.257 & Partial \\
\hline
\end{tabular}

Notes: $* * * p<0.01$, ns: not significant, ${ }^{\text {a }}$ The total indirect effect was calculated (for the procedure, see Preacher and Hayes 2008), ${ }^{\mathrm{b}}$ Specific indirect effects

In addition, we tested the Customer Satisfaction $(\beta=0.281, p=0.000)$ and perceived Vitality of Local Services $(\beta=0.268, p=0.000$ ) effects of recommending a local store (measured in a single item) both directly and indirectly through Local Store Patronage $(\beta=0.377, p=0.000)$. We also conducted a multi-group moderation analysis between the respondent groups from rural and urban areas, and we tested the moderating effect between Local Engagement and Local Store Patronage using the number of additional services as the moderator. However, none of these tested moderating effects were found to be statistically significant.

\section{Discussion and conclusions}

The impacts of social environment factors contributing to local retail patronage have been studied in the literature on marketing (Landry et al. 2005; Noble et al. 2006) and small business management (Miller and Kean 1997; Besser 1999; Miller and Besser 2013). While most previous studies have focused on the socialization actions of local retailers (e.g., engaging in local communities, supporting local communities), we aimed to investigate the drivers of local grocery retail patronage from the consumers' point of view, focusing on consumers' personal values and social embeddedness to explain local retail patronage.

Our results contribute to the literature on retail patronage in several ways. Contrary to Pioch et al. (2009), who argued that economic norms (value price, convenience) are dominant factors explaining retail patronage, our results show the relative importance of social factors in determining local retail store choice among customers, thus supporting the importance of societal legitimacy (cf., Handelman and Arnold 1999) in the local retail context.

Moreover, our findings support and extend the findings regarding the relationship between local engagement and store patronage reported in previous studies (Miller 2001; Kim and Stoel 2010). Miller (2001) found that community attachment has a significant indirect effect on inshopping behavior, mediated by reciprocity. Similarly, our results indicate that the link between consumer local engagement and store patronage is indirect, not direct. However, our 
study establishes the important mediating role of perceived vitality of local services to explain the relationship between consumer local engagement and local store patronage.

Third, we demonstrate that social interaction plays an important role in affecting local store patronage. Thus, our results support the findings of Landry et al. (2005) who reported a positive relationship between social interaction and local store patronage. However, while Landry et al. (2005) studied community embeddedness by surveying customers of a single small store in the western region of the United States, our study examined consumer attitudes using a national level analysis. Similarly, our findings from a county with a developed market economy are in line with the results reported in studies examining retail markets in developing countries. For example, Maruyama and $\mathrm{Wu}$ (2014) found that Chinese consumers who place more importance on communication with salespeople are more likely to shop at traditional neighborhood markets.

Fourth, we extend the earlier understanding of the role of customer satisfaction in determining grocery retail patronage. Previous research has focused on consumer satisfaction in different store formats and for different types of shopping. For example, Nilsson, Gärling, and Marell (2013) showed that consumers are more satisfied with supermarkets than convenience stores, and Nilsson et al (2017) found that consumers are more satisfied with fill-in shopping than major shopping. The study of Hsu et al. (2010) conducted in a U.S. college town showed that customer satisfaction was not related to geographical proximity of a grocery store. On the contrary, our findings showed that satisfaction is a key determinant for local grocery store patronage. In particular, we demonstrate the important mediating role of social interaction in determining the relationship between consumer satisfaction and local retail patronage. In other words, consumers who value social interaction with friends and store personnel during a shopping trip seem to be more satisfied with their local store, and eventually, they tend to visit that store more often.

In addition, we show that perceived satisfaction with vitality of local services affects the intention to recommend a local store both directly and indirectly through local store patronage. This research provides empirical evidence that satisfaction is linked with loyalty in the retailing context (Bridson et al. 2008; Dixon et al. 2005; Grosso and Castaldo 2015; Nesset, Nervik, and Helgesen 2011), and that there are differences in how satisfaction affects a consumer's repurchase intention and recommend intention. Although recommend intention and repurchase intention are considered attitudinal constructs in the present study, it seems that prior positive experiences with a local store are more important for local store patronage than for recommend intention. This finding reinforces the need to assess and manage these two types of loyalty separately in an attempt to better understand customer behavior (de Matos and Rossi 2008; Watson et al. 2015). Our additional findings differ from the results reported in earlier studies, which indicate that satisfaction has a stronger positive effect on additional loyalty than behavioral loyalty (Watson et al. 2015; Leppäniemi, Karjaluoto, and Saarijärvi 2017). Our findings also elucidate that perceived vitality of local services and local community as well as local store patronage manifest as the intention to encourage friends to visit a local store.

Pan and Zinkhan's (2006) meta-analysis of earlier findings in patronage literature noted that gender was the only demographic variable having a strong effect on store patronage. Similarly, Noble et al. (2006) showed that gender is a key predictor of local merchant loyalty. Females were more loyal to local retailers than males; they considered local retailers to be an important part of the local community. However, our results did not find a relationship between gender and local grocery store patronage. 


\section{Managerial implications}

Based on the theoretical contribution addressed above, the present study's results have implications for managers. First, our study suggests that retailers could engage customers to shop locally by reinforcing their commitment to the local community and increasing the vitality of local services by participating in community events and community development in those areas in which they are located. Consequently, retailers can also encourage store personnel to interact with customers in order to increase their commitment to shop locally. According to Johnstone (2012), consumers' patronage choices are not always based on the commercial activities that occur within the store space; they are also based on the interactions between customers and service personnel. Loyalty can be interpreted as a feeling of interpersonal trust towards the store personnel and/or to other customers that favor the same store. Effectively managing social factors could help local grocery retailers stand out from their competitors and avoid losing customers to supermarkets that are able to provide lower prices and broader selection.

\section{Limitations and future research}

Because shopper motivations can vary across retail sectors (Geuens, Brengman, and Rosette 2001), we caution that our findings may not be generalizable to other retail and service domains. Thus, the importance of social factors in determining patronage in other retail sectors might be different from the factors that determine patronage in the grocery sector.

In this study, we did not consider the impact of the length of the customer relationship on patronage behavior. Because previous research in apparel retailing (Reynolds and Beatty 1999) has shown that longer-term customers perceive higher social benefits, further studies could investigate if the length of the customer relationship has an effect on patronage behavior in local grocery stores.

The concept of local store patronage can be determined either based on ownership (i.e., stores locally owned and operated) or geography (i.e., stores locating in close proximity to a consumer) (Noble et al. 2006). In the present study, we used geographic orientation, focusing on customer patronage behavior in grocery stores located near the consumers' homes (whether owned by a local independent retailer or a national chain). In addition, due to the specific characteristics of Finnish grocery retailing, the majority of the local small grocery stores are run by national chain-based retailers, which have a dominant market share. Therefore, the study results should be treated with caution when attempting to draw conclusions about patronage behavior in locally-owned small retail stores.

\section{Notes on contributors:}

Mika Skippari, $\mathrm{PhD}$, works a research director in the Faculty of Management at the University of Tampere. His research interest include competitive strategies and consumer behavior in retail markets. His recent research has been published in Industrial Marketing Management, Business History, and Business \& Society.

Jussi Nyrhinen, M.Sc. Econ, is a doctoral student in marketing. He currently works as a researcher at the University of Jyväskylä School of Business and Economics. His research focuses on the consumption of experiences across physical and digital platforms. His research delves themes of ethical marketing, health and wellbeing and the social aspect of consumption. 
Heikki Karjaluoto, $\mathrm{PhD}$, is a professor of Marketing at the University of Jyväskylä, Finland, and the leader of the Digital Marketing Research group. His research interests include customer relationship management, marketing communications, mobile communications, and retail banking. Previous publications have appeared in the Business Strategy and the Environment, Computers in Human Behavior, European Journal of Marketing, Industrial Marketing Management, and others.

\section{References}

Autio, M., and V. Heinonen, 2004. "To Consume or not to Consume? Young People's Environmentalism in the Affluent Finnish Society." Young - Nordic Journal of Youth Research 12 (2): 137-153.

Arnold, S. J., J. Handelman, D.J. Tigert. 1996. "Organizational Legitimacy and Retail Store Patronage." Journal of Business Research 35 (3): 229-239.

Arnold, M. J., and K. E. Reynolds. 2003. "Hedonic Shopping Motivations." Journal of Retailing 79 (1): 77-95.

Bhattacharya, C.B., and S. Sen. 2003. "Consumer-Company Identification: A Framework for Understanding Consumers' Relationships with Companies." Journal of Marketing 67 (2): $76-88$.

Bell, D. R., D. Corsten, and G. Know. 2011. "From Point of Purchase to Path to Purchase: How Preshopping Factors Drive Unplanned Behavior." Journal of Marketing 75 (1): 31-45.

Besser, T. L. 1999. "Community involvement and the perception of success among small business operators in small towns." Journal of Small Business Management 37 (4): 1630.

Besser, T. L., and N. J. Miller. 2013. "Community Matters: Successful Entrepreneurship in Remote Rural US Locations." The International Journal of Entrepreneurship and Innovation 14 (1): 15-27.

Bhat, S. and R. Fox. 1996. "An Investigation of Jeopardy Effects in Store Choice". Journal of Retailing and Consumer Services 3 (3): 129-33.

Brennan, D. P., and L. Lundsten. 2000. "Impacts of Large Discount Stores on Small US Towns: Reasons for Shopping and Retailer Strategies." International Journal of Retail and Distribution Management 28 (4/5): 155-161.

Bridson, K., J. Evans, and M. Hickman. 2008. "Assessing the Relationship between Loyalty Program Attributes, Store Satisfaction and Store Loyalty." Journal of Retailing and Consumer Services 15 (5): 364-374.

Carpenter, J., and M. Moore. 2006. "Consumer Demographics, Store Attributes, and Retail Format Choice in the US Grocery Market." International Journal of Retail and Distribution Management 34 (6): 434-452.

Clarke, I., and S. Banga. 2010. "The Economic and Social Role of Small Stores: A Review of UK Evidence." The International Review of Retail, Distribution and Consumer Research 20 (2): 187-215.

Coca-Stefaniak, J. A., C. Parker, and P. Rees. 2010. "Localisation as a Marketing Strategy for Small Retailers." International Journal of Retail \& Distribution Management 38 (9): 677-697.

Coleman, J. S. 1988. "Social Capital in the Creation of Human Capital." American Journal of Sociology 94 (Supplement): S95-S120.

Cowell, D. K., and G. P. Green. 1994. "Community Attachment and Spending Location: The Importance of Place in Household Consumption.” Social Science Quarterly 75 (9): 637655. 
Cummins, S., A. Findlay, M. Pettigrew, and L. Sparks. 2008. "Retail-Led Regeneration and Store-Switching Behaviour." Journal of Retailing and Consumer Services 15 (4): 288295.

Dacin, M. T. 1997. "Isomorphism in Context: The Power and Prescription of Institutional Norms." Academy of Management Journal 40 (1): 46-81.

de Matos, C. A., and C. A. V. Rossi. 2008. "Word-of-mouth Communications in Marketing: A Meta-analytic Review of the Antecedents and Moderators." Journal of the Academy of Marketing Science 36 (4): 578-596.

Dixon, J., J. Bridson, J. Evans, and M. Morrison. 2005. "An Alternative Perspective on Relationships, Loyalty and Future Store Choice." The International Review of Retail, Distribution and Consumer Research 15 (4): 351-374.

Finnish Grocery Trade Association (PTY). 2017. "Annual Review of the Finnish Grocery Trade Association." http://www.pty.fi/fileadmin/user_upload/tiedostot/Julkaisut/ Vuosijulkaisut/EN_2017_vuosijulkaisu.pdf.

Ganesh, J., K. E. Reynolds, and M. G. Luckett. 2007. "Retail Patronage Behaviour and Shopper Typologies: A Replication and Extension Using a Multi-format, Multi-method Approach." Journal of the Academy of Marketing Science 35 (3): 369-381.

Geuens, M., M.Brengman, and S.Rosette. 2001. "An Exploratory Study of Grocery Shopping Motivations." European Advances in Consumer Research, edited by A. Groeppel-Klien, and E. Frank-Rudolf, (5): 135-140. Provo, UT: Association for Consumer Research.

Goswami, P., and M. S. Mishra. 2009. "Would Indian Consumers Move from Kirana Stores to Organized Retailers when Shopping for Groceries?" Asia Pacific Journal of Marketing and Logistics 21 (1): 127-143.

Granovetter, M. 1985. "Economic Action and Social Structure: The Problem of Embeddedness.” American Journal of Sociology 91 (11): 481-510.

Grewal, D., J. Baker, M. Levy, and G. B. Voss. 2003. "The Effects of Wait Expectations and Store Atmosphere Evaluations on Patronage Intentions in Service-Intensive Retail Stores," Journal of Retailing 79 (4): 259-268.

Grosso, M., and S. Castaldo. 2015. "How Store Attributes Impact Shoppers' Loyalty: Do Different National Cultures Follow the Same Loyalty Building Process?" The International Review of Retail, Distribution and Consumer Research 25 (5): 503-515.

Handelman, J. M., and S. Arnold. 1999. "The Role of Marketing Actions with a Social Dimension: Appeals to the Institutional Environment". Journal of Marketing 63 (3): 3348.

Henseler, J., C. M. Ringle, and M. Sarstedt, 2015. "A New Criterion for Assessing Discriminant Validity in Variance-based Structural Equation Modeling." Journal of the Academia of Marketing Science 43 (1): 115-135.

Home, N. 2002. "Rural Consumers' Patronage Behaviour in Finland." The International Review of Retail, Distribution and Consumer Research 12 (2): 149-164.

Hozier, G. C., and D. E. Stem. 1985. "General Retail Patronage Loyalty as a Determinant of Consumer Outshopping Behavior." Journal of Academy Marketing Science 13 (1): 3246.

Hsu, M. K., Y. Huang, and S. Swanson. 2010. "Grocery Store Image, Travel Distance, Satisfaction and Behavioural Intentions - Evidence from a Midwest College Town." International Journal of Retail and Distribution Management 38 (2): 115-132.

Huddleston, P., J. M. Whipple, R. N. Mattrick, and S. J. Lee. 2009. "Customer Satisfaction in Food Retailing: Comparing Specialty and Conventional Grocery Stores." International Journal of Retail and Distribution Management 37 (1): 63-80 
Jayasankaraprasad, C., and K. Gonuguntla. 2014. "Cross-format Shopping Motives and Shopper Typologies for Grocery Shopping: A Multivariate Approach.” The International Review of Retail, Distribution and Consumer Research 24 (1): 79-115.

Johnstone, M.-L. 2012. "The Servicescape: The social dimensions of place." Journal of Marketing Management 28 (11-12): 1399-1418.

Kim, J., and L. Stoel. 2010. "Factors Contributing to Rural Consumers' Inshopping Behavior: Effects of Institutional Environment and Social Capital." Marketing Intelligence \& Planning 28 (1): 70-87.

LaBarbera, P. A., and D. Mazursky. 1983. "A Longitudinal Assessment of Consumer Satisfaction/Dissatisfaction: The Dynamic Aspect of the Cognitive Process." Journal of Marketing Research 20 (4): 393-404.

Landry, T. D. T. J. Arnold, and J. B Stark. 2005. "Retailer Community Embeddedness and Consumer Patronage." Journal of Retailing and Consumer Services 12 (1): 65-72.

Leppäniemi, M., H. Karjaluoto, and H. Saarijärvi. 2017. "Customer Perceived Value, Satisfaction, and Loyalty: The Role of Willingness to Share Information." The International Review of Retail, Distribution and Consumer Research 27 (2): 164-188.

Lombart, C., and D. Louis. 2012. Consumer Satisfaction and Loyalty: Two Main Consequences of Retailer Personality. Journal of Retailing and Consumer Services 19 (6): 644-652.

Maruyama, M., and L. Wu. 2014. "Quantifying Barriers Impeding the Diffusion of Supermarkets in China: The Role of Shopping Habits." Journal of Retailing and Consumer Services 21 (3): 383-393.

Megicks, P. 2007. "Levels of Strategy and Performance in UK Small Retail Businesses." Management Decision 45 (3): 484-502.

Miller, N. J. 2001. "Contributions of Social Capital Theory in Predicting Rural Community Inshopping Behavior." Journal of Socio-Economics 30 (6): 475-493.

Miller, N. J., and R.C. Kean, 1997. "Factors Contributing to Inshopping Behaviour in Rural Trade Areas: Implications for Local Retailers." Journal of Small Business Management 35 (2): 80-94.

Miller, N.J. and Kim, S. (1999), "The importance of older consumers to small business survival: evidence from rural Iowa." Journal of Small Business Management 37 (4): 115.

Miller, N. J., and T. L. Besser. 2000. "The Importance of Community Values in Small Business Strategy Formation: Evidence from Rural Iowa." Journal of Small Business Management 38 (1): 68-85.

Miller, N. J., T. L. Besser, L. A. Gaskill, and S. G. Sapp. 2003. "Community and Managerial Predictors of Performance in Small Rural US Retail and Service Firms." Journal of Retailing and Consumer Services 10 (4): 215-230.

Morschett, D., B. Swoboda, and T. Foscht. 2005. "Perception of Store Attributes and Overall Attitude Towards Grocery Retailers: The Role of Shopping Motives." International Review of Retail, Distribution and Consumer Research 15 (4): 423-447.

Nesset, E., B. Nervik, and Ø. Helgesen. 2011. "Satisfaction and Image as Mediators of Store Loyalty Drivers in Grocery Retailing." The International Review of Retail, Distribution and Consumer Research 21(3): 267-292.

Nilsson, E., T. Gärling, and A. Marell. 2013. "Consumers' Satisfaction with Grocery Shopping in Supermarkets and Convenience Stores." International Journal of Sales, Retailing and Marketing 2 (4): 72-90.

Nilsson, E., T. Gärling, A.-C. Nordvall, and A. Marell. 2015. "Who Shops Groceries Where and How? - The Relationship between Choice of Store Format and Type of Grocery 
Shopping." The International Review of Retail, Distribution, and Consumer Research 25 (1): $1-19$.

Nilsson, E., T. Gärling, and A. Marell. 2017. "Effects of Time Pressure, Type of Shopping, and Store Attributes on Consumers' Satisfaction with Grocery Shopping." The International Review of Retail, Distribution and Consumer Research 27 (4): 334-351.

Noble, S. M., D. A. Griffith, and M. T. Adjei. 2006. "Drivers of Local Merchant Loyalty: Understanding the Influence of Gender and Shopping Motives," Journal of Retailing 82 (3): 177-188.

Pan, Y., and G. R. Zinkhan. 2006. "Determinants of Retail Patronage: A Meta-analytical Perspective." Journal of Retailing 82 (3): 229-243.

Paswan, A., M. de los Dolores Santarriaga Pineda, and F. C. S. Ramirez. 2010. "Small Versus Large Retail Stores in an Emerging Market-Mexico." Journal of Business Research 63 (7): 667-672.

Pioch, E., U. Gerhard, J. Fernie, and S. J. Arnold. 2009. "Consumer Acceptance and Market Success: Wal-Mart in the UK and Germany." International Journal of Retail \& Distribution Management 37 (3): 205-225.

Preacher, K. J., and A. F. Hayes. 2008. "Asymptotic and Resampling Strategies for Assessing and Comparing Indirect Effects in Multiple Mediator Models." Behavior Research Methods 40 (3): 879-891.

Reynolds K. E., and S. E. Beatty. 1999. "Customer Benefits and Company Consequences of Customer-Sales Person Relationships in Retailing." Journal of Retailing 75 (1): 11-32.

Runyan, R. C., and C. Droge. 2008. "A Categorization of Small Retailer Research Streams: What Does It Portend for Future Research?” Journal of Retailing 84 (1): 77-94.

Scott, W.R. 1987. "The Adolescence of Institutional Theory". Administrative Science Quarterly 32 (4): 493-511.

Sinha, P. K., and A. Banerjee. 2004. "Store Choice Behaviour in an Evolving Market." International Journal of Retail and Distribution Management 32 (10): 482-494.

Suchman, M. 1995. "Managing Legitimacy: Strategic and Institutional Approaches." Academy of Management Review, 20 (3): 571-610.

Sullivan, P., and R. Savitt. 1997. "Store Patronage and Lifestyle Factors: Implications for Rural Grocery Retailers." International Journal of Retail \& Distribution Management 25 (11): 351-364.

Tauber, E. M. 1972. "Why Do People Shop?” Journal of Marketing 36 (4): 46-49.

Uncles, M.D., and S. Kwok. 2008. "Generalizing patterns of store-type patronage: An analysis across major Chinese cities." The International Review of Retail, Distribution and Consumer Research 18 (5): 473-493.

Watson, G. F., J. T. Beck, C. M. Henderson, and R. W. Palmatier. 2015. "Building, Measuring, and Profiting from Customer Loyalty." Journal of the Academy of Marketing Science 43 (6): 790-825.

Wilska, T-A. 2002. "Me, A Consumer? Consumption, Identities and Lifestyles in Today's Finland". Acta Sociologica 45 (3): 195-210.

Zeithaml, V. A., L. L. Berry, and A. Parasuraman. 1996. "The Behavioural Consequences of Service Quality.” Journal of Marketing Management 60 (2): 31-46. 


\section{Appendices}

Appendix 1. The items used to measure the variables.

\section{Local Store Patronage}

- I usually buy my groceries at my local grocery store.

- I believe that I will visit my local grocery store more often in the future.

- How often do you visit your local grocery store?

\section{Local Engagement}

- I like to participate in events in my local community.

- There is lot of cooperation between the people in my local community.

- The vitality of my local community is important to me.

- For me, it is personally important that there is lot of cooperation between people.

Social Interaction

- Personal service is important to me.

- It is important to me that the store manager or the store personnel know me personally.

- I like to meet acquaintances while I shop for my groceries.

Vitality of Local Services

- I prefer to shop for my groceries in my local grocery store to support local services.

- The vitality of local services is important to me.

- It is important for me that my local grocery store employs people from the local community.

\section{Customer Satisfaction}

- I am satisfied with the location of my local grocery store.

- I am satisfied with the opening hours of my local grocery store.

- I am satisfied with the quality of the goods and services offered by my local grocery store. 